\title{
TAKING THE ANALYSIS OF SECURITY SERIOUSLY
}

\author{
Alan Schwartz*
}

\section{INTRODUCTION}

DROFESSORS Harris and Mooney ("H \& M") argue that the 1 new Article 9 should further advance the goals of the current statute-to make security easier to take and to increase its scope. ${ }^{1}$ $\mathrm{H} \& \mathrm{M}$ defend this position against attacks from Law and Economics analysts and other scholars; both sets of critics, $H$ \& $M$ claim, want to imcrease the costs associated with secured credit or otherwise to restrict its use. $\mathrm{H} \& \mathrm{M}$ 's article primarily attempts to refute the Law and Economics claims; it cites few other scholars and only discusses the economic arguments in detail. This Commentary thus focuses on the dispute that $\mathrm{H} \& \mathrm{M}$ have with Law and Economics. $H$ \& M's support for Article 9 has both a positive and a normative aspect. The former argues first that the debate over the efficiency of secured debt is inconclusive as a matter of theory; the granting of security sometimes creates net social benefits and sometimes does not. $H$ \& $M$ go on to claim that whether the former effect usually occurs "is an empirical question that cannot be answered with any certainty using existing information." 2 The law nevertheless should facilitate the issuance of secured debt because normative grounds exist to allocate the burden of proof in the security interest debate to Article 9's opponents. First, security often is indistinguishable in its economic effects from other transactions, such as sales and the repayment of debts, that the state generally facilitates. This creates a presumption that the state should facilitate the creation of security interests. Second, a debtor that issues security is merely alienating its property. That our society encourages freedom of alienation generally strengthens the normative presumption that society should encourage the issuance of security.

* Sterling Professor of Law, Yale Law School; Professor, Yale School of Management. Stephen Morse and George Triantis made helpful comments on prior drafts.

1 Steven L. Harris \& Charles W. Mooney, Jr., A Property-Based Theory of Security Interests: Taking Debtors' Choices Seriously, 80 Va. L. Rev. 2021 (1994).

2 Id. at 2036. 
The opponents of security cannot overcome the normative presumption that security should be facilitated, given the theoretical and empirical uncertainties that $\mathrm{H} \& \mathrm{M}$ expose. ${ }^{3}$ Hence, legislators should act as if the desirability of security is established.

$\mathrm{H} \& \mathrm{M}$ do not advance the "security interest debate." Two questions have figured largely in this debate. First, how, if at all, does a later security-financed project alter the value of earlier debt? Second, why would a firm finance projects with secured debt rather than unsecured debt or equity? $\mathrm{H}$ \& $\mathrm{M}$ only address the first question because they mistakenly suppose that an answer to it determines the answer to the second. As Part I of this Commentary shows, these questions are distinct. Consequently, $H$ \& M's focus on the first question prevents them from illuminating the issue why security exists. Part I also shows that $\mathrm{H} \& \mathrm{M}$ answer the first question incorrectly. Part II then argues that H \& M's appeal to property theory fails. That theory justifies restricting voluntary transactions that either create externalities or are affected by imperfect information, two market imperfections that may be associated with secured debt. Part II next shows how these imperfections may justify giving security less favorable treatment than current law now does. Consequently, property theory, properly understood, does not support $\mathrm{H} \&$ M's normative claim respecting the manner of allocating the burden of proof in the security interest debate. Parts I and II, taken together, thus exhibit the weakness of $\mathrm{H} \& \mathrm{M}$ 's defense of Article 9. Finally, the Conclusion suggests that writing an article from the perspectives of a law reformer and a scholar, which $\mathrm{H} \& \mathrm{M}$ attempt here, is harder to do than is commonly believed, for these perspectives can conflict.

3 H \& M summarize their normative claim as follows:

[T] hose who would question ... the wisdom of generally respecting security interests bear a heavy burden. They must attack directly the respect that the law generally affords the free and effective alienability of property rights or (more plausibly) explain why, based on distributional concerns, the law should treat security interests differently from other transfers of property interests. No one has met that burden. We doubt that anyone will.

Id. at 2053. 


\section{The Economics of Security}

\section{A. A Simple Debt Valuation Model $^{4}$}

The value of a firm is the sum of the value of the claims to the firm's cash flow: debt represents a fixed claim on the firm's income whereas equity represents the residual claim to current and future cash flows (dividends and growth opportumities). $H$ \& $M$ assume the existence of a firm that has outstanding debt. The value of such a firm is $v_{1}=e_{1}+d_{1}$, where $v$ is firm value, $e$ is the value of the equity claim, and $d$ the value of the debt claim. ${ }^{5}$ This firm then finances a second positive value project with secured debt. $H \& M$ ask what effect the second project has on the earlier unsecured debt.

To answer this question, realize that the value of a debt claim is the sum of two present values: (1) the face amount that the debtor promises to repay discounted by the probability that the debtor will actually repay in full and (2) the expected amount the creditor will recover if the debtor defaults (which is less than the first amount). It is helpful to write down a smiple expression for the value of the imitial debt claim (" $\mathrm{d}_{1}$ ") for $\mathrm{H} \&$ M's firm. Let the firm promise to repay the face value of the debt (" $d_{f}$ ") at a certain time (" $t$ "). If the firm defaults and becomes insolvent, the creditor will recover $\alpha \mathrm{d}_{\mathrm{f}}$, where $0 \leq \alpha<1$. This says only that the creditor's bankruptcy share will be less than the face value of the debt. A dollar repayable at time $t$ when the interest rate is $r$ has present value ("PV") of

$$
\operatorname{PV}(\$ 1)=\frac{1}{(1+r)^{t}}
$$

Let this value be $\delta^{t}$ and let $\pi$ be the probability that the debtor will repay. Then the value of the initial debt $d_{1}$, before a later project is taken, is

$$
\mathrm{d}_{1}=\delta^{\mathrm{t}}\left[\pi \mathrm{d}_{\mathrm{f}}+(1-\pi) \alpha \mathrm{d}_{\mathrm{f}}\right]
$$

A later debt-financed project can have two opposite effects on the value of earlier unsecured debt. First, because the number of

${ }^{4} \mathrm{H}$ \& $\mathrm{M}$ do not write down a formal model but rather proceed by giving a series of examples. This Section sets out the model from which their examples can be generated.

5 Subscripts are used to indicate that the firm will later incur more debt in the course of doing more projects. Each element of the equation is in present value terms. 
debt claims on the firm has increased, the initial unsecured creditor must share the firm's assets on default with more creditors. If the second loan is financed on an unsecured basis, however, the initial creditor can reach some of the assets the second project brought into the firm. If the second loan is secured, the second lender can take all of these assets (up to the value of its claim). Thus although the issuance of later debt always reduces the value of $\alpha$ (the fraction of the original debt that the initial unsecured creditor will recover in bankruptcy), the issuance of later secured debt reduces $\alpha$ the most. ${ }^{6}$ Holding all other values constant, when $\alpha$ falls, the value of the initial debt $d_{1}$ falls as well. Hence, later debt-financed projects may reduce the value of prior debt. This effect is greatest when the later debt is secured.

Respecting the opposite effect, the later project's returns may correlate highly imperfectly with returns from the firm's earlier projects, or the later project may just be very lucrative. In either case, taking the later project could increase the probability that the debtor will repay the earlier loan. First, the lower the correlation among the firm's return streams, the more diversified the firm's project portfolio becomes, and diversification generally reduces risk. Second, if the later project generates returns that are much in excess of costs, these returns could be used to cushion losses on prior projects: this effect also will reduce the default probability. Holding all else constant in the equation for the value of $d_{1}$, when $\pi$, the repayment probability, increases, the value of $d_{1}$ increases. This is because the first value in the equation, the promised repayment $d_{f}$, is larger than the second value in the equation, the initial lender's bankruptcy share $\alpha \mathrm{d}_{\mathrm{f}}$. Increasing the weight of the higher, first value (increasing $\pi$ ) while reducing the weight of the second, lower value (decreasing $(1-\pi)$ ), necessarily increases the value of $\mathrm{d}_{1}$. Thus a later debt-financed project could increase (or at least not reduce) the value of earlier debt.

In sun, the effect of a debt-financed project on the value of prior debt is ambiguous as a matter of theory. On the one hand, the later debt reduces the value of the prior debt because it reduces

${ }^{6} \mathrm{H} \& \mathrm{M}$ thus say: "Our analysis acknowledges that UC [the initial creditor] and other unsecured creditors are better off if their debtor incurs unsecured rather than secured debt (on the assumption that the present value of each unsecured creditor's claim in insolvency would be slightly larger in the former case)." Harris \& Mooney, supra note 1, at 2035. 
that debt's expected bankruptcy payoff ( $\alpha$ falls). On the other hand, the existence of the later debt-financed project could increase the payoff probability for the earlier debt ( $\pi$ increases). If the latter effect dominates the former (or just cancels it), then later debt will not reduce (and may increase) the value of prior debt.

A later debt-financed project that generates revenue in excess of cost (in present value terms) is pareto efficient if the project does not reduce the value of earlier debt. The new net revenue accrues to the equity, making it better off. Also, the later lender earns a return on the second loan (otherwise it would not have lent), and the earlier lender's return is preserved. Thus, the later project makes some persons better off while making no one worse off.

According to $H \& M$, this result is relevant to the security interest debate. They assume that the second project in their examples could not be financed unless the firm gave the later lender a security interest. ${ }^{7}$ On this view, granting security is pareto efficient when the later project is profitable, and the repayment probability effect of that project on prior debt dominates (or cancels) the reduction-in-bankruptcy-share effect attributable to the granting of security. Because the repayment effect sometimes could be the more important, security sometimes is efficient (at least in theory). Therefore, the issue is empirical: which of these countervailing effects on prior debt commonly is the more important? H \& M believe that there is no convincing data relevant to this question. They then conclude that the case against security is inconclusive on theoretical grounds and unproven on empirical grounds, and consequently turn to property theory to settle the issue.

\section{B. Problems with $H$ \& M's Argument}

$\mathrm{H} \&$ M's argument is wrong on the facts and irrelevant to the theoretical issue. Respecting the facts, recall that the repayment probability effect on prior debt can dominate the reduction in bankruptcy share effect if (1) second project returns are highly imperfectly correlated with first project returns or (2) the second project is very lucrative. Because firms tend to do related projects, the first effect apparently is uncommon. Because firms tend to do the best projects first, and because wonderful projects are rare, the

7 Id. at 2030. 
second effect also seems uncommon. Thus armchair empiricism suggests that the reduction-in-bankruptcy-share effect usually is the more important. ${ }^{8}$

There is a way to choose between this view and H \& M's view regarding the facts. If later unsecured debt commonly reduced the value of prior unsecured debt and if later secured debt reduced that value still further, then (1) initial lenders commonly would exact covenants from debtors prohibiting the debtors from borrowing elsewhere without the earlier lender's consent and (2) initial lenders even niore commonly would prohibit debtors from later issuing security. On the other hand, if later debt does not reduce the value of prior debt as a rule, these contract terms should be unusual. The facts clearly show that the predicted terms are standard: loan covenants that restrict the abihty of debtors to borrow elsewhere are very common, and negative pledge clauses, which prohibit later secured borrowing, are almost ubiquitous. ${ }^{9}$ Therefore, there is no empirical uncertainty respecting the effect of later secured debt on earlier unsecured debt: the former reduces the value of the latter. ${ }^{10}$

This empirical result does not end debate on the question whether it is efficient for a firm to take a later project. To be sure, later positive value projects that do not reduce the value of prior debt are pareto efficient. Later positive value projects can be Kaldor-Hicks efficient, however, even when they reduce the value of the prior debt. This occurs when later project returns are sufficiently high to overcome the reduction in value. ${ }^{11}$ That later debtfinanced projects may be pareto or Kaldor-Hicks efficient, how-

8 These points were made previously in Alan Schwartz, A Theory of Loan Priorities, 18 J. Legal Stud. 209, 231 (1989).

9 See id. at 216-18; Alan Schwartz, Contracting for Priority Positions 22 (1993) (unpublished manuscript, on file with the Virginia Law Review Association). A recent study also found that, in a sample of public debt issues rated A or higher, over $90 \%$ of them restricted the borrower's ability to incur future liens. Mai E. Iskandar-Datta \& Douglas R. Emery, An Empirical Investigation of the Role of Indenture Provisions in Determining Bond Ratings, 18 J. Banking \& Fin. 93, 97, 99 tbl. 2 (1994).

10 Earlier analyses, such as mine, that assumed that the reduction in bankruptcy share effect dominated the repayment probability effect thus were well grounded.

I1 Leveraged buyouts commonly generated gains for target shareholders that exceeded the losses to earlier, unprotected bondholders; thus, those buyouts were Kaldor-Hicks efficient. The analysis in Part I assumes, with $\mathrm{H} \& \mathrm{M}$, that the firm has no nonconsensual claimants. 
ever, is irrelevant to the theoretical issues in the security interest debate.

This is because the question whether security is efficient requires a theory of finance to answer, not a theory of asset pricing (that tells, inter alia, how to value a debt claim). To see what is meant, it is helpful to return to basics. The value of a firm is the value of the claims to the firm's cash flow. The famous Modigliani and Miller ("MM") result holds that, on the assumptions they make, a firm cannot increase the present value of its cash flow by altering its capital structure. As a consequence, firm value will remain the same whether the firm finances the projects that generate its cash flow with debt, with equity, with a combination of the two, or with instruments more exotic than simple debt or equity. The MM result thus predicts that capital structure is a matter of indifference to firms. The facts contradict this prediction: firms spend considerable time and money creating the financial instruments that constitute their capital structures.

This leads to a profound puzzle: according to MM, resources spent to create financial instruments are a dead weight loss because those costs cannot generate gains; a firm's value is invariant to its capital structure. Are firms that otherwise appear to maximize profits behaving irrationally with respect to their capital structures? The modern theory of finance responds to this question by attempting to show how the method of financing projects can increase the net revenue those projects generate. In the absence of such a showing, the MM puzzle remains.

In 1981 and again in 1984, I wrote about what I called the puzzle of secured debt. ${ }^{12}$ My argument in brief was this: the existence of later secured debt would commonly reduce the value of earlier unsecured debt (reduce $d_{1}$ in the model above). Initial creditors then would either bar later security (so it would not be seen) or raise their interest rates to make up for the loss in value of their loans. On my assumptions, the rise in interest rates would exactly offset the decline in value of the unsecured debt, so security could not create gains for the firm. Because it was costly to issue secur-

12 See Alan Schwartz, The Continuing Puzzle of Secured Debt, 37 Vand. L. Rev. 1051 (1984); Alan Schwartz, Security Interests and Bankruptcy Priorities: A Review of Current Theories, 10 J. Legal Stud. 1 (1981). 
ity, again no secured debt should be observed. This led to an MMlike puzzle: If secured debt generates costs but does not increase the revenues froin the projects it finances, why is so much security seen? I then considered whether security could reduce a firm's financing or production costs or increase its gross revenues. Either effect would increase firm value and thus justify incurring the costs of issuing security. The various possibilities of how security could reduce costs or increase revenues did not seen promising. Thus, for me, the security interest puzzle remained. ${ }^{13}$

$\mathrm{H} \& \mathrm{M}$ make no progress with this puzzle. They argue that security is efficient when the second project in their examples could not be pursued unless security were issued, and when the later debt would not reduce the value of the prior debt. To see why this is not responsive, recall that projects generate cash flows (revenues less costs). The present value of a firm thus is the present value of the sum of its projects. If financing any of these projects with secured debt is costly but cannot increase project returns, then the firm should not use secured finance at all; the costs of doing so are wasted.

$\mathrm{H} \& \mathrm{M}$ assume that a creditor will only finance the later project in their examples on a secured basis. This is initially odd because the firm, in those examples, was able to finance its initial projects on an unsecured basis. More deeply, creditors cannot force firms to waste inoney. If investor 1 offered to lend a firm $\$ \mathrm{x}$ if the firnn, in addition to paying the market interest rate, put ten $\$ 100$ bills in a pile and burned them, investor 2 could make positive returns by offering a deal to supply the $\$ \mathrm{x}$ without requiring a fire.

The security interest puzzle, like the MM puzzle on which it is based, holds that when the method by which a project is financed cannot increase the revenue from that project, the resources spent on issuing security are wasted. Incurring these costs amounts to

13 I later came to see that a firm could increase its value by granting its initial financer the highest priority rank if (1) potential lenders were imperfectly informed about the quality of the projects a firm may take and (2) the firm had no nonconsensual claimants. See Schwartz, supra note 8, at 235-41; Schwartz, supra note 9. Why some firms choose to grant initial financers priority with loan covenants while other firms use security remains an unanswered question. $\mathrm{H} \& \mathrm{M}$ assume that potential creditors are well informed about project quality. Thus, their work is in the MM (and in my earlier) framework, where all relevant actors are symmetrically informed. 
torching dollars. Thus the relevant theoretical question is not whether a later secured-debt-financed project can increase firm value (at least, in theory). Later unsecured-debt-financed projects also can increase firm value. The question is why any project, late or early, is financed with secured debt rather than unsecured debt, equity, retamed earnings, or soinething else.

$\mathrm{H} \&$ M's inethod is therefore equivalent to calculating the rate at which objects fall and then claiming one has explained why objects fall at that rate. To do the former, one needs only a knowledge of matheinatics and eyes; to do the latter, one needs a theory of gravity. Similarly, $H$ \& $M$ attempt to calculate the effect of a later secured loan on the value of prior debt and then claim that they have explained why firms issue security. To do the former, one again needs a knowledge of matheinatics and the eyes to observe that secured debt often is seen; to do the latter, one needs a theory of finance-a theory that shows how the method of financing a project can increase the returns that the project generates. $\mathrm{H}$ \& $\mathrm{M}$ have no such theory.

In summary, $H$ \& $M$ have inade no progress in explaiming why firns issue security or how secured finance is inore efficient than any other form of finance. Further, security does reduce the value of earlier debt. These deficiencies vitiate the positive aspect of their argument in favor of security. The normative aspect of that argument is taken up next.

\section{H \& M's Burden of Proof Argument}

\section{A. Security and Private Property}

H \& M's normative arguinent for allocating the burden of proof to Article 9's opponents in the security interest debate is unpersuasive because their reliance on property theory is too simple. As a consequence, $\mathrm{H} \& \mathrm{M}$ never meet the real challenge from Law and Economics.

Beginning with the former difficulty, $\mathrm{H} \& \mathrm{M}$ argue that property theory shows the undesirability of restraining freedom of alienation. Applying this theory, they then argue that secured transactions are relevantly like sales and debt repayments, both of which the state generally encourages. This appeal to property theory is too simple because it ignores the possibility of market failure. To 
see why this matters, recall that transactions such as sales and repayments are considered presumptively desirable under two conditions: (1) the relevant transaction affects only the parties to it; and (2) those parties are symmetrically informed about the economic parameters. When both of these conditions are satisfied, voluntary transactions are highly hikely to make the parties to them better off and no one else worse off. The existence of security in business contexts raises normative concerns precisely because these conditions may not always be met in connection with secured financing: such financing may harm third parties (e.g., tort claimants), and the parties to secured loans may be asymmetrically informed. When externalities or imperfect information exist, our society commonly does and should respect voluntary transactions less. Thus, the question whether the state should facilitate the issuance of security cannot be answered without considering these possible market imperfections. ${ }^{14}$

$\mathrm{H} \& \mathrm{M}$ do not discuss externalities and asymmetric information. Instead they proceed by analogy, arguing that security is relevantly identical to otlier voluntary transactions that the law encourages. I will give just one example (there are others) of low this analogical method leads them astray. $\mathrm{H} \& \mathrm{M}$ claim that a debtor that makes a caslı sale may cause as muclı or more liarm to its creditors as it would if it granted one creditor a security interest. A debtor that gives security retains all of its assets. It could use these assets, $\mathrm{H} \& \mathrm{M}$ say, in sucl fashion as to reduce the probability of default on other loans, or it could not. Similarly, in a cash sale, "[w]liether the expected return to creditors will increase or decrease depends on whether $\mathrm{D}$ [the debtor] makes more productive use of the casli received or of the asset sold."15 Thus, botli sales and security can be helpful or harmful, depending on the particular facts. If society

14 I previously argued that property theory implies the freedom to mortgage in consumer contexts. See Alan Schwartz, The Enforceability of Security Interests in Consumer Goods, 26 J.L. \& Econ. 117, 152-60 (1983). Consumers do not pursue business projects that creditors may have difficulty valuing but rather have jobs the income from which creditors can observe. Also, consumers as a rule do not commit torts or take other actions that could impose significant costs on third parties. When neither asymmetric information nor externalities are present, I argued, consumers should have the freedom to mortgage. Id. at 160-61.

15 Harris \& Mooney, supra note 1, at 2040. 
resolves this factual issue in favor of encouraging sales, consistency requires society also to encourage security.

To see what is wrong with this analogy, recall that the value of an asset is the net present value of the return stream that the asset generates. Let that value be $v_{\mathrm{a}}$. If the firm sold the asset and invested the cash in another project (or put it in the bank), it would turn the cash into an asset the value of which, $v_{c}$, is the net present value of the return stream that the invested cash generates. The firm would inake a less "productive use of the cash" asset if $v_{a}>v_{c}$.

A sale in this circumstance, however, would be irrational. The firm has no reason to sell an asset it values at $\$ 100\left(v_{a}\right)$ for $\$ 90$ cash $\left(v_{c}\right)$. H \& M's argument thus takes this form: (1) voluntary transactions are desirable because they maximize the utility of the parties to them; (2) this occurs because parties can act rationally in their own self-interest; (3) sales and secured transactions can have similar economic effects; (4) this similarity occurs because sellers cannot act rationally in their own self-interest (they sometimes sell property for less than it is worth); (5) therefore, secured transactions should be given the saine respect as sales. Because steps (2) and (4) are inconsistent, the conclusion-step (5)-does not follow.

$\mathrm{H} \& \mathrm{M}$ get into such deep water because security cannot be defended by analogy. Rather, its strengths and defects must be directly analyzed. ${ }^{17}$

\section{B. Possible Inefficiencies Associated with Security}

Law and Economics scholars who examine security do not question the general wisdom of encouraging voluntary transactions. Rather, they ask whether market imperfections that inay be associated with secured transactions are sufficiently serious to justify a regulatory response. $\mathrm{H} \& \mathrm{M}$ do not discuss these market imperfections and so do not contribute to the debate. This Section briefly

16 Id.

$17 \mathrm{H} \& \mathrm{M}$ apparently do not claim that freedom of alienation is a deontological liberty good. That claim could not be refuted by showing that security may be inefficient; rather, an opponent would have to show that the costs associated with security are so excessive as to interfere with the liberty of other persons. 
discusses asymmetric information and third-party effects that may be associated with the use of security.

\section{Asymmetric Information and a Simple Signaling Model}

Borrowers are sometimes said to give security to signal that they are good risks, but signaling equilibria can be inefficient. Consider a simple model: (1) lenders cannot directly observe the quality of the projects that firms bring to market; (2) a higher quality project has a lower risk of default; (3) the cost to a firm of giving security varies inversely with the quality of its projects; (4) credit markets are competitive.

There are three equilibria in this model. In one "pooling equilibrium," no firms issue security, creditors remain uminformed about project quality, and the market interest rate is a risk-weighted average. In a second "separating equilibrium," firms with good projects issue more security than firms with bad projects. To see how this equilibrium could arise, assumption (2) implies that firms with good projects would like to tell lenders the facts in order to get lower interest rates, but assumption (1) implies that lenders will not believe mere claims that a project is good. Assumption (3) then implies that a firm with a good project can make credible disclosure: because the cost to a firm of giving security falls as its projects improve in quality, firms with good projects can offer security, or a lot of it, whereas firms with poor projects would find it more costly to issue security, or as much. A separating equilibrium thus may exist in which firms with the best projects give the most security and are charged the lowest rates while firms with poorer projects give less security or none and are charged higher rates.

A second pooling equilibrium also may exist, however. In it, all firms issue security, so security interest signals are not illuminating. This equilibrium occurs when the higher interest rate costs that firms with bad projects would incur if creditors were to recognize them as being bad would exceed the costs that such firms would incur from issuing security. In this event, the bad firms would defect from the separating equilibrium by sending security interest signals-i.e., by borrowing secured.

The second pooling equilibrium is inefficient relative to the others. In the first pooling equilibrium, creditors are uninformed, 
but firms save the costs of issuing security; in the separating equilibrium, security costs are incurred but loans are priced more accurately because creditors have more information; in the second pooling equilibrium, however, security interest costs are incurred while creditors remain uninformed. Thus, signaling in this equilibrium is "dissipative": issuing security is privately optimal for firms (the lower imterest rate exceeds the cost), but the security interest signals are socially wasteful because they do not improve loan pricing. Recent theoretical analyses show that the inefficiencies from "dissipative signaling" can be worse than the inefficiencies associated with other forms of pooling. When that occurs, it is efficient to restrict the abihty of firms to signal. As applied lere, restricting security thus can be efficient in theory. ${ }^{18}$

This analysis does not yet justify restricting security for two reasons. First, given the current state of the theory, it is difficult to know just when dissipative ratler than informative signaling occurs. Second, signaling models sometimes predict badly, which counsels caution. ${ }^{19}$ Nevertheless, the theory indicates that when information is asymmetric, parties take actions, often in theory and sometimes in life, that are privately optimal but socially inefficient. As a consequence, defenses of security that fail to consider asymmetric information are incomplete.

\section{Third-Party Effects}

To understand third-party effects, consider a set of tort claimants who are not in a bargaining relationship with tlie firm that injures them. If the injurer is not fully insured and if actual victims will get little in the injurer's bankruptcy, then potential victims may take excessive precautions to avoid harm. This inefficiency can be ame-

18 Arguments that welfare in asymmetric information environments can be improved by restricting private contract, including the ability to send contractual signals, have been made by Philippe Aghion \& Benjamin Hermalin, Legal Restrictions on Private Contracts Can Enhance Efficiency, 6 J.L. Econ. \& Organization 381 (1990), and Ian Ayres \& Robert Gertner, Strategic Contractual Inefficiency and the Optimal Choice of Legal Rules, 101 Yale L.J. 729 (1992). An interesting dissipative signaling model that deals extensively with security is presented in Arnoud W.A. Boot, Anjan V. Thakor \& Gregory F. Udell, Secured Lending and Default Risk: Equilibrium Analysis, Policy Implications and Empirical Results, 101 Econ. J. 458 (1991).

19 See Francine Lafontaine, Contractual Arrangements as Signalling Devices: Evidence from Franchising, 9 J.L. Econ. \& Organization 256 (1993). 
liorated by increasing the tort claimants' expected bankruptcy payoff. Doing tliat, however, would make secured credit less desirable to take. This effect of helping tort claimants would count against reform if secured credit uncontroversially increases welfare. Then tlie decisionmaker would liave to compare tlie "tort inefficiency" of inducing excessive precautions to the "credit mefficiency" of reducing the desirability of secured credit. On the otlier hand, if the nature and extent of tlie latter inefficiency are hard to identify, the case for lielping tort claimants becomes stronger by default. ${ }^{20}$

The policy issue tliat third-party effects raises thus is not wliether secured credit should be burdened simpliciter. Ratler, tlie question that the Law and Economics scliolars raise concerns the desirability of the current bankruptcy priority scheme. $H$ \& $M$ never discuss nonconsensual bankruptcy clamiants and tlius liave nothing to say to this question.

\section{CONCLUSION}

$H$ \& M's defense of Article 9 is unpersuasive. These authors fail to show why security exists or wlietlier it commonly creates net social gains. Moreover, $\mathrm{H} \& \mathrm{M}$ do not seriously consider inefficiencies, arising from externalities and asymmetric information, tliat may be associated with security. Thus, they have no answer to attacks on security that rest on tlie existence of these species of market failure. The existence of possible market failure also vitiates $H$ \& M's attempt to allocate the burden of proof in tlie security interest debate to Article 9's opponents. That attempt rests on the alleged analogy between security contracts and other contracts that the law encourages. These latter contracts, however, seldom are plausibly associated with market failure.

In my view, $H$ \& $M$ do not succeed, because they fail to take the analysis of security seriously. The authors state as their "first principle' that Umiform Commercial Code Article 9 should facilitate the creation of security interests."21 This assumes wliat scholars sliould demonstrate. Were $H$ \& $M$ to have asked instead whether Article 9 sliould facilitate the creation of security interests,

20 The relation between tort and bankruptcy law is complex. For a brief discussion, see Schwartz, supra note 8 , at 257-59.

21 Harris \& Mooney, supra note 1, at 2021. 
they might have made serious use of the modern theories of finance and property, and thus made fewer errors. $H \& M$ serve as Reporters for the Drafting Committee to revise Article 9. Perhaps the constraints associated with that role would cause any scholar to slight fundamental questions, such as whether Article 9 itself is a good idea. But then perhaps Reporters should not try to write basic articles. 
